\section{Contested Commodifications}

\author{
Struggles over Nature in a National Park
}

TANIA MURRAY LI

A national park is supposed to be pristine nature, a place where flora and fauna A national park is supposention, the are left to thrive without disturbance. For it with a particular kind of value-an intrinsic value, the value of a global heritage, a priceless treasure. For them, a park is the ultimate noncommodity. If they discuss the commodity value of park is the ultimate nrovides, it is not to assert the commodity status of nature the services nature provides, it is not to assert the corks in a world dominated itself, but as a tactic to promote the survival of parks in a wimilarity between the by commodity thinking. ${ }^{1}$ Further, despite the structural sim similarity especially enclosure of a park and the enclosure of a plantation-a similarity especially visible for the victims of such an enclosure-conservationists do not se the projects in these terms. As Peluso and Nevins point out in their introductic conservationists see their effort as part of what Karl Polanyi $(2001,141)$ called countermovement - the endeavor to protect the noncommodity status of the a co maintenance of life. Yet the projects of establishing both the wildness and the noncommodity status of a park are best understood as just that-as projects, not as established facts. They are seriously unconvincing to the people most affected by these renderings of nature, namely, people living in the vicinity of parks who pay a tangible price for conservation when they are colde from the use of park resources. In this chapter I explore contestions ext the wildness and the noncommodity status of protected nature, drawing a sulawesi's Lore Lindu National Park.

The term project twists together two threads of meaning: (1) the verb to project-to imagine or fantasize a particular scenario, as a slide show projects images on a blank screen; (2) the noun, a project, a purposive activity intended to bring about definite results. As Cronon (1996) and others have pointed out, nature-as-wilderness is projected in these ways. It invokes the fantastical notion of the untouched, yet it needs to be produced by practices of enclosing land, excluding farmers, and erasing signs of human labor and habitation. In the sar manner people, if they are to be included in a park, must be projected as natur loving, and produced to conform. Park border villagers, as I will show, have counterproject, namely, to reclaim the right to use and sell park resources. Thi also have a counterprojection, as they imagine that people professing an intere in conservation are driven by the search for economic gain.

\section{Counterprojections}

Villagers who live around the Lore Lindu National Park and draw part of the livelihoods from it do not see the park as a noncommodity. They see it rath as a site of struggle in which different commodifications contend. They ther selves are fully involved in a market economy. Working under the protectio of and with financing from well-placed officials and entrepreneurs, they extrac timber and rattan from the park for sale. They also clear patches of forest $t$ grow commodities: coffee, since the colonial period, and cacao since the 1990 s when Sulawesi became one of the world's largest producers. In the past they als grew food there. Market values circa 2000 were such that the main objective o park-border villagers was growing cacao, a brown gold offering the prospect o money to pay for food, school fees, better houses and clothes, and other desirabl goods. When conservation organizations attempted to stop them from carryin out their market-oriented activities, villagers attributed their motives not to th protection of the park as a noncommodity but to an alternate commodification that competed with their own. In the villagers' projection they were "small people" oppressed by greedy and powerful outsiders who wanted to profit from the park's resources at their expense.

I caught a glimpse of the villagers' counterprojection in 2003 when I heard park-border villagers offer a literal translation for the conservationists' claim that the park was "the property of the world," or a "global biodiversity resource." Villagers informed me that government officials had sold the park or divided it up between "nine nations" as payment or guarantee for Indonesia's foreign debts. Their tale of "nine nations" probably referred to an Asian Development Bank loan of US $\$ 32$ million to the government of Indonesia, represented by the Forest Department, for an "integrated conservation and development" project that was supposed to protect the park. As the villagers imagined it, officials had mortgaged the park to the foreigners in return for project funds. If the conditions of the loan were not met-if the park was not protected-the foreigners would retrieve their money by laying claim to the park itself. The villagers were convinced that the foreigners had profit motives. If they did not want to profit from the park, why would they want to control it? Behind the talk of conservation, villagers suspected the foreigners wanted to sell off the park's genetic resources or mine there for gold. 
The villagers also projected profit motives onto the officials who stood to gain from the existence of the $\mathrm{ADB}$ project and its associated income streams. As they saw it, officials had used a techno-scientific rationale as a ploy to withdraw sources of livelihood from villagers in order to create sources of livelihood for themselves. They knew for sure that some corrupt officials already were profiting from the park by organizing the "illegal" timber and rattan extraction. In relation to this particular commodification-one in which some villagers also participatedtheir objection was framed in terms of fairness and matters of scale.

"We are true to the constitution," a villager named Pak Ratu informed me. "The constitution says the land and water belong to the people, for their wellbeing.... It is the officials who are breaking the law. If we are wrong, they are more wrong. The logging companies steal timber on a big scale. Why are only the small people faulted? It should be fair." Pak Ratu had been sent to attend Indonesia's preparatory meeting for the 2002 Johannesburg environment conference (a decade after Rio), an experience that had broadened his critical vocabulary. "Political ecology," he said, "means 'who is it for?" At issue for Pak Ratu was not whether the park should be commodified, but whose commodifying practices would prevail-a question intimately related to who would reap the profits, and who would pay the price.

Contested commodifications also entered into the sad story told to me by Mama Yonas, a woman living inside the park on land that she had occupied in concert with a thousand households claiming to be landless and calling themselves the Free Farmers Forum.

We didn't have land [in the valley]. We were share-cropping sawah [wet rice fields]. To get somewhere, you need to have land. So in 2000 we decided to try in the park. We came in with twenty people, to clear two hectares. The usual pay was 5,000 rupiah but I offered my workers 10,000 rupiah because the work was hard-they had to cut big trees.

Then a party of forest guards came by, fifteen of them. They came to my hut. I was getting the food ready for the workers. The workers ran to hide. They thought I had been arrested. So I gave the guards coffee and food: They stayed for one hour to eat. Then they said, "It's time for us to go. Do you know this is inside the park?" I said I know, but I need to eat. They asked me what I planned to plant. I told them candlenuts, cacao, durian, to replace the trees. I said I have nothing in [the valley]. They said, "Excuse us now" [i.e., they politely took their leave]. Then they started hacking at my hut and everything I had planted, cut it all to pieces, burned it down. I cried. I said, "God will see you. You have no pity." They just smiled. My cacao, coffee, chili peppers, they pulled it all up.

I asked them, "Don't you eat chilies too? We are just going to grow crops, not take the land." They said, "You can't do that here, this place belongs to lots of nations" [banyak Negara yang pegang ini]. So I thought, does this belong to Indonesia or to some other country? If it belongs to Indonesia, it belongs to me too. Then they left. My workers came back, and went right back to work, because I had already paid them. They went back to work, clearing the forest, brave- until it was all done. It was cleared, but we hadn't planted yet. ${ }^{2}$

What Mama Yonas asserted was not a right to customary land, or to use nature in "customary" ways. It was an entitlement to land as a basis for livelihood in the context of a market economy. This kind of claim has been especially problematic for the park authorities and conservation organizations because it is difficult to contain. The livelihood needs of Sulawesi villagers are infinite, as is the population that might want a share of the park land to farm. Villagers all around the park circa 2000 were indeed making bold claims, cutting down trees to plant the new boom crop, cacao. They justified their actions in terms of customary rights to land used by their ancestors, wrongfully stolen from them when the park boundaries were demarcated or, as in the case of Mama Yonas, on the grounds of the right of citizens to access the resources needed for a decent life. The involvement of foreigners and the language of global values only strengthened their sense
of local entitlement.

I will now contextualize villagers' counterprojections in the history of agrarian relations in this part of Sulawesi, and then examine the conservationists' project of producing the right kind of natives to fit the niche in nature potentially available to villagers living in and around the Lore Lindu National Park-natives who would opt for conservation over profit.

\section{Sulawesi Highlanders and Other Awkward Subjects}

In his magisterial book Nature's Government: Science, Imperial Britain, and the Improvement of the World, Richard Drayton stresses the centrality of the idea of the profligate native in the justification of colonialism - the idea that "whoever was on the spot was wasting its resources, and... might legitimately be expelled, or submitted to European tutelage" $(2000,232)$. This myth is alive and well in national bureaucracies and transnational agencies that promote agricultural development and conservation. As Peluso and Nevins observe, it continues to be used to justify dispossession. Ruling regimes backed by science use a particular population's failure to improve (to turn nature's bounty to a profit) or to conserve (to protect nature for the common good) as justification to reassign resources to parties capable of making proper use of them. ${ }^{3}$

In Sulawesi, the first part of the myth of the profligate native-the failure of natives to turn resources to a profit-is rather easily refuted by reference to the villagers' evident proficiency in and commitment to market-oriented production. Yet this refutation runs up against well-intentioned efforts to defend villagers from the second part of the myth-that which accuses them of being poor stewards of nature. Although a few villagers have benefited from presenting 
themselves as nature-loving natives capable of contributing to conservation goals, most find this niche highly constrained. For conservationists prepared to include villagers in park management, Sulawesi highlanders are awkward subjects. Some background will help to explain why this is so.

For more than a century, villagers in Central Sulawesi have been enthusiastic commodity producers. They needed no coercion to take them to market-so long as the price and the conditions were just. In the highlands, which was subdued by conquest around 1910, Christian missions and the edifice of colonial administration depended on the capacity of the natives to pay taxes, school tuition, and church dues. Thus highlanders were coerced into coffee production in the early years, but they became keen producers of the crop as soon as flexible market channels were established and the price increased. In the Palu Valley colonial offichannels were established and the price increased. In the Paired household to plant fifty coconut trees and an extra ten per additional family member (Weber, Faust, and Kreisel 2003, 414). Yet their coercion was superfluous: farmers in the Palu Valley had been planting coconuts since the seventeenth century, and they relied on the copra and oil as a source of income and a means to pay tribute. From the 1880 s onward they planted millions more trees in response to good prices. Enthusiasm for commercial crops continued after conquest. Indeed, colonial officials observed this enthusiasm, since they issued further instructions that food production should not be neglected. ${ }^{4}$ Concern that villagers would neglect food production in favor of commodities was a frequent refrain in the colonial archive across Southeast Asia, especially in the uplands. The problem, as officials saw it, was not how to make villagers into market subjects, but how to prevent them from responding to booming prices in ways that threatened colonial interests by stimulating large-scale migrations, increasing the need for imported food, outcompeting plantation-based production, or causing villagers to withhold their labor from the plantation economy. 5 The struggle - then as now-was not over forcing produce onto the market, but over the distribution of costs and benefits.

Specifically in relation to the Lore Lindu National Park, struggles over the costs and benefits of market-oriented production intensified in the late 1990s as smallholder enthusiasm for cacao threatened the project of nature conservation. The reason for this particular threat was local and specific, situated as it was at the conjuncture of several forces: (1) a massive rise in the price of cacao related to the crash of the rupiah in 1997-1998; (2) the low capital, low-tech character of caca in its early stages, making it ideal as a smallholder crop: in 2001, 80 percent of Indonesia's cacao production was smallholder based; (3) an increase in population in the vicinity of the park, caused by poorly planned resettlement schemes and the spontaneous migration of smallholders seeking land for cacao; (4) processes of agrarian differentiation among smallholders, as some accumulated land and others were effectively dispossessed; (5) large-scale enclosures of land for plantations and the state-claimed forest, closing off the avenue of retreat-and of hope-for the landless; (6) increased enforcement of park boundaries as transnational conservation agencies supplied financing to step up park protection. ${ }^{6}$

This was the context in which landless farmers such as Mama Yonas took desperate measures to reclaim land from the park for smallholder production of cacao, at the risk of violent eviction-her own bitter experience. But enforcement could not keep pace with the pressure presented by thousands of landhungry would-be cacao producers in the villages surrounding the park. It was in this context that the park-based conservation lobby, headed by The Nature Conservancy, set to work on another front: projecting park-border villagers as nature-loving allies in conservation and seeking to make their behavior conform by misrecognizing - and curbing-their market-oriented activities.

\section{Making Categories Real}

In the context of the villagers' interest in cacao, the project of producing natureloving "natives" of a kind suited for inclusion in the park's management regime seems especially heroic. From the perspective of conservation experts concerned about the park, its natural landscapes should either be uninhabited or populated by people whose livelihoods and identities could be assimilated to nature. This assimilation is a projection, what Larry Lohman (1993) calls a "green orientalism" that involves making up an exotic story about a certain group of people and then imposing this fantasy on them. ${ }^{7}$ Natives are nature loving; otherwise, they are not real natives. Yet producing natives to fit the slot conservationists have devised is no easy task.

Classificatory schemes, as Timothy Mitchell (2002) points out, are not models of the world, they are models for it. Arguably, producing suitably nature-loving natives is more difficult than producing disciplined labor, a project that can be accomplished by coercive means, including absolute dispossession. In the case of Lore Lindu, people living in and around the park had some choices. It was not easy to make them conform. Here I analyze the efforts of one conservation organization, The Nature Conservancy (TNC), and the elaborate scheme for naturalnative production outlined in its 2001 draft management plan for the park. ${ }^{8}$

Faced with villagers' challenge to the legitimacy of the park and its boundaries and their desire to commodify park resources their way, TNC devised a containment strategy that focused on the system of park zonation. Since it was impossible to exclude people from the park entirely, TNC's goal was to confine human activities to the Traditional Use Zone, which made up 13 percent of the park's land area. Yet this was not simply a matter of acknowledging the villagers' existing practices and claims. The purpose of the Traditional Use Zone, according to the 1990 Conservation Law, was to allow "limited resource extracrion of locally occurring species" (TNC 2002b, 2:100). The use zone had as its imagined subject traditional villagers gathering indigenous resources for use in 
traditional, noncommercial ways. This concept fits uneasily with the reality of resource use inside the park. Nevertheless, for TNC fit had to be attempted in order to contain the villagers' challenge. The use-zone concept provided some room for maneuver and compromise. TNC expected that park-border villagers who were granted access to the Traditional Use Zone would be willing to sign conservation agreements binding them to stop agricultural "encroachment," timber extraction, and other "illegal" activities in a quid pro quo. For this to work, actors and activities suitable for the use zone had to be identified. This was much easier said than done.

One obvious problem was that many of the resources present in the park and valued by villagers are not actually indigenous-they are exotic. Ecologists advising TNC produced a long list of exotics that should ideally be eliminated both from the park and, even more contentiously, from surrounding villages. The list included coffee, cacao, dogs, cats, chilies, carp, deer, tilapia, and water buffalo (TNC 2002b, 2:65, 178). A second major problem was that the usezone provision prohibits commercial extraction of resources (TNC 2002b, $2: 69)$. It assumes that traditional systems of resource extraction prioritize subsistence use. This is incorrect. From around 1870, commerce has driven the ebbs and flows of resource extraction from the forests of Indonesia (Boomgaard 1997). Damar resin from the trees enclosed by the park was collected and exported for at least a century (1870-1970), and rattan was a major export in the 1980 s and 1990s when many villagers derived a major part of their incomes from that source. A third problem was identifying an appropriate subject to fill the niche of the "traditional" villager, embedded in an appropriately traditional community. In this matter one particular village, Katu, emerged in a prominent but troubled role.

\section{Troubles with Tradition}

Katu village is located inside the park boundaries. It was slated for resettlement under the $\mathrm{ADB}$ project. With the help of some NGOs, Katu villagers mounted a strong campaign that resulted in the formal recognition of their right to remain in their village. The park director accepted their argument that they were indigenous people who held customary rights to land and resources enclosed by the park, and who had traditional wisdom concerning resource management and conservation. In this way, the Katu people and their allies successfully countered one of the myths identified by Drayton: the myth that profligate natives cannot be trusted with nature protection. Although TNC had opposed the park director's decision to let Katu village remain inside the park, it later turned the presence of Katu to its advantage, as Katu offered TNC an opportunity to make the category "traditional resource use" real. It served as a placeholder for the concept of traditional management anticipated in the use zone. It also served to mark a boundary, to explain why the rights and privileges of Katu did not apply to other, more ordinary park border villages. Katu was used, that is, to contain a much broader political challenge. But the containment was precarious. Park-border villagers disputed Katu's status as an especially traditional place, and they emphasized the need of all the park-border villagers for access to agricultural land. TNC's experts were also concerned that Katu might turn out to be rather ordinary, that is to say, market oriented, and worked hard to define and maintain the grounds of distinction.

The draft plan noted the disjuncture between concepts of tradition and existing practice. To qualify for the use zone, villagers-including Katu villagers-would have to demonstrate that they were indeed traditional. Put differently, concepts of tradition would serve to limit what villagers could do in the park. Thus, according to the draft plan, "Application of adat or customary practice would, presumably, restrict hunting to indigenous communities who have traditional hunting grounds. Techniques would, presumably, have to be traditional, thus ruling out the use of guns and wire snares" (TNC 2002b, 2:67). Set against these presumptions, Katu's practices were found to be deficient. Although the park director applauded the interest that the people of Katu showed in restoring their old rice terraces and planting them with biodiverse strains of local rice, he was disappointed when his exemplary traditional subjects joined the rush to plant cacao (TNC 2002b, 2:167). Less inclined to trust the wisdom of tradition, the TNC experts writing the draft plan argued that managers, not villagers, must decide which practices would be forbidden or permitted in Katu, guiding the villagers on an appropriate path (TNC 2002b, 2:84-86).

Making distinctions between social groups and allocating rights according to those distinctions was a central feature of the draft plan. In addition to the axis of indigenous/nonindigenous and traditional/nontraditional, the plan emphasized the distinction subsistence/commercial, sometimes amalgamated with a concept of scale (small/large). In relation to agriculture, for example, enforcement efforts were to distinguish between a subsistence farmer and a "commercial coffee planter" (TNC 2002b, 2:90). This might seem quite an appropriate distinction, appealingly populist, but it was disrupted by the actual pattern of livelihoods around the park. Almost all the coffee grown in the park in 2001 was sold, and no farmers in the vicinity of the park had coffee groves bigger than about four hectares. There was no distinct practice of subsistence coffee growing, nor was there a distinct class of "commercial coffee planters." Yet on the basis of this and related distinctions, the draft plan developed a scheme for classifying land users and determining the kinds of "action" that should be taken to control, reduce, or eliminate their activities. These sets of distinctions were set out in the following figure.

The classificatory grid formalized in the figure proposed a set of distinctions through which park authorities could apprehend, redirect, and manage extractive 


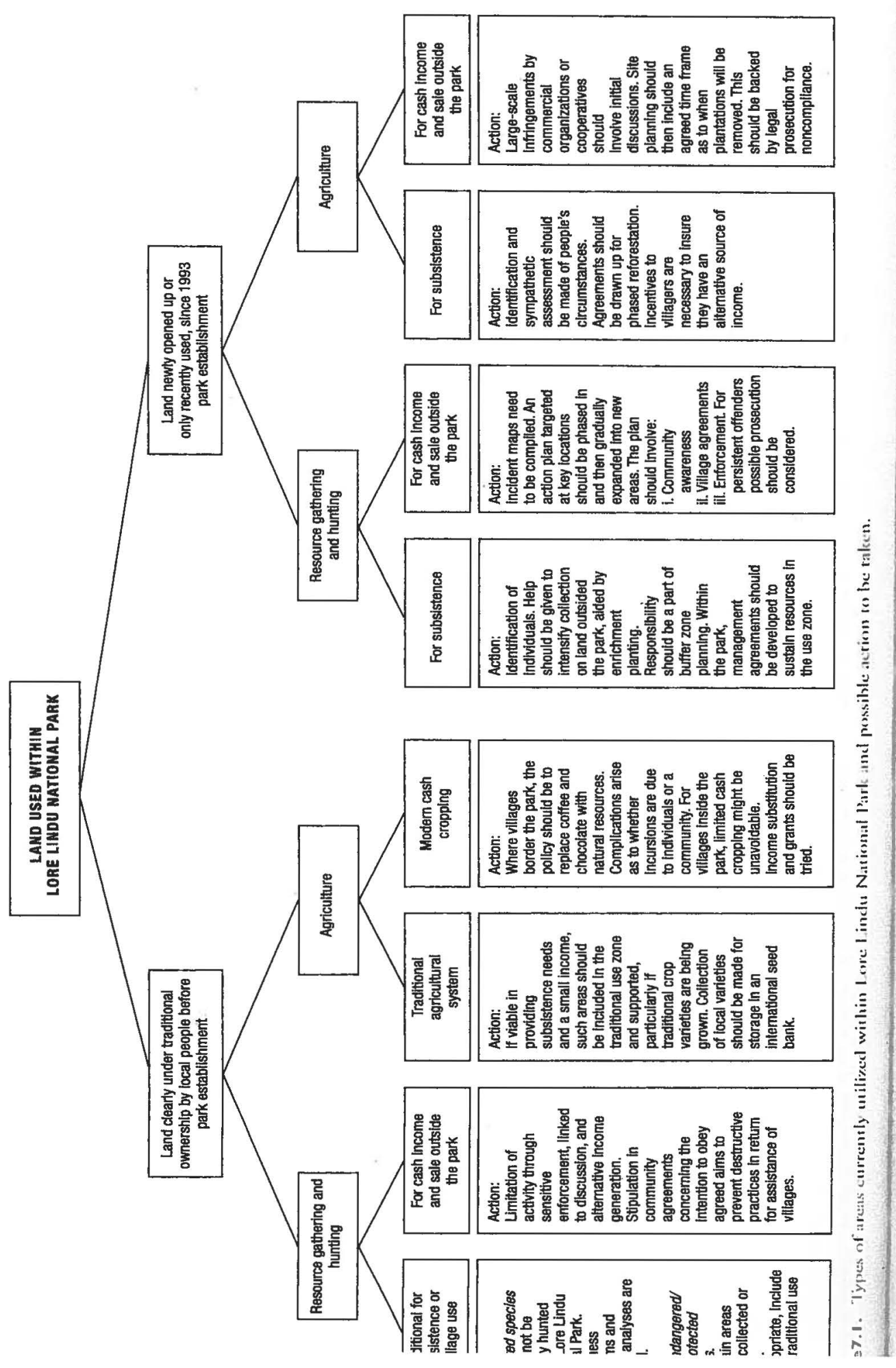

and agricultural activities within the park. Yet, as I have explained, there was a gap between the reality of the grid and reality in and axound the parthis could not be left unfilled. The draft management plan called for "precise mapping," the listing of "those people certified to explo called for "precise mapand the preparation of protocols "specifying exploit resources within the zone, " type of community activities with actual people and places that met . The boxes on the grid had to be filled (The maps, lists, and prohad to be approved in scientific, legal, and bureaucratic scrutiny, since they $2002 \mathrm{~b}, 2$ 107). How could proved to be just as awlould be done? In the effort to fill the grid, scientists rattan "management."

\section{Rattan Regimes}

Rattan extraction was one activity potentially permitted in the Traditional Use Zone. To qualify, it had to be sustainable and "traditional." The draft plan proposed that rattan collection, which was "claimed as a traditional activity but in "tight control years has become a major local business," should be subject to allowed at measures, including codes of practice"-if, indeed, it was to be entific atudy (TNC 2002b, 2:66). To help fill the grid, TNC sponsored a scicondutud by findings of the study, management strategy. Siebert's repert late 1990s, did not support the preferred tain tainable harvesting as an "ecological fallacy" based in "utopian thinking." He was skeptical that technical criteria and practices for "sustainable harvesting" from forests could be devised. Despite widespread interest there were, he wrote, "few, if any, documented examples." Even if guidelines for sustainable rattan extraction could be devised, he pointed out that there was no scientific basis for predicting the sustainability of the park ecosystem as a whole. He also argued that the concept of sustainable extraction assumed that ecosystems, property regimes, and markets were stable and that extraction could in fact be controlled (TNC 2002b, $2: 155)$. His study demonstrated that none of these conditions were present in
relation to rattan in the park.

The idea that subsistence could be separated from commerce was a nonstarter in Siebert's two study villages west of the park in the 1990s. In one of these, subsistenten incomes to meet subsistence needs, and in Au the number was 58 percent. The search for ratremote vill, further, had attracted landless households to move into these rather remote villages-mainly indigenous highlanders who had sold off their land to incoming migrants busy buying up land for cacao. But by around 2000 Siebert found that interest in rattan collection was declining because there were no more 
suitable canes within ten kilometers of the villages, and alternative and more lucrative opportunities had become available (TNC 2002b, 2:149). Given the "phenomenal increase in the value of cacao," he argued, "it is unclear whether rattan will continue to be as economically important to area households at it has been in the recent past, and thus whether [villagers] will invest capital and labor in its management" (TNC 2002b, 2:157). 9

Siebert also questioned the concept of customary rattan management. Minimally, management requires territorial exclusion. He found that the village head of Moa had attempted to declare an exclusive harvesting zone reserved for villagers. Outsiders could access the rattan only with permission. His study showed, however, that the headman's rules were not familiar to Moa's long-time "traditional" residents or to outside rattan collectors, still less were they enforced. Without tenurial security vis-à-vis the park and other collectors, the incentive for "sustainable management" was effectively zero. Thus, Siebert argued, in the case of the park a rattan tenure and management system would have to be devised and implemented from scratch. It could not simply build on "tradition" or "custom" as proponents of sustainable management assumed. The connection between village and territory was also precarious. A catastrophic flood in Au had cut the village in half, destroyed rice fields, and caused residents to relocate two kilometers downstream, far from the zone that would have been carefully mapped, classified, and monitored for their "traditional use" under TNC's draft plan. After the flood he found the people of Au "so busy rebuilding homes and rice fields, and planting cacao, that no one appears to be gathering rattan" (TNC 2002b, 2:156).

Based on his research Seibert concluded that programs for the community management of wild rattan should not be developed. Instead he recommended interventions to increase the productivity and sustainability of cacao and coffee on privately owned and managed lands outside the park, and the addition of cultivated rattan to the repertoire of farm-based perennials where farmers showed an interest (TNC 2002b, 2:157-59). Rattan, in short, was not a resource that villagers had an interest in "managing" in the park's use zone. Nor, argued Siebert, were there any other forest products of sufficient value to compete with cacao.

Although Siebert's report was included in the draft plan, complete with its dissident conclusions, TNC opted to ignore the scientist's advice. The TNC plan for the design of the Traditional Use Zone was premised on the concept of sustainable gathering of forest products according to traditional norms and new monitoring protocols that would bring expert knowledge, conservation requirements, and village interests into alignment. Thus the draft plan stated that Siebert's recommendations were "not in keeping with the general approach to resource issues within the Park. The way forward is generally perceived to be through Community Agreements" (TNC 2002b, 2:69).

\section{Collaborative Management}

Collaborative management was intended to fill the space on the grid reserved for conservation-oriented villagers who would assist the authorities in monitoring activities taking place within the park. According to the draft managemen plan, monitoring was to be conducted jointly by forest guards and villagers. A report on a monitoring exercise sponsored by TNC in a village east of the park revealed the difficulty of making this category real. The exercise was designed to measure the extent of damage to the forest on the village edge by means of transects. The results would be compiled in a database entered into a GIS system for long-term comparison and decision making by people-villagers as well a ined villagers? Why would vill to protect the park. ${ }^{10}$ But who were these imagined villagers? Why would villagers want to help supply the park authorities with details of the "damage" their farming and extractive activities caused to the park? What interest, if any, did they have in biodiversity monitoring? Another conservation project at Lore Lindu also built a significant part of its-program around "biodiversity monitoring systems." It envisaged the practice of monitoring as an educational tool to "precondition" the border population to move toward regulated resource use (CARE 2003, 6). It was a technique designed not so much to produce data as to produce new, environmental subjects. ${ }^{11}$ But as the midterm evaluation of this project observed, a similar initiative elsewhere in Sulawesi had already been abandoned because of the "lack of clear legal basis... and misgivings among locals about [the] utility of [the] system" (CARE 2002, 21).

The park director, who recognized the villagers of Katu as "an integral part of the Park Management system," was an enthusiastic promoter of village monitoring to detect and expel illegal loggers and rattan collectors. In his plans, monitoring by villagers would be backed by customary councils that would arrest the culprits and impose heavy fines. It would also be backed by a strengthened forest police supplied with more guns (ADB 2002, annex 14). This plan took no account of the way that some villagers profit from logging. The director assumed that logging was a net minus for villagers--the source_of damage to their water supply, or the accusation that they were the ones engaged in illegal activity. $\mathrm{He}$ also overlooked the complicity of village officials and park guards in the logging, in organizing village labor and providing local "security" for logging syndicates. $\mathrm{He}$ overlooked the ways village leaders compete over the spoils, factionalizing their own villages, and compete with outsiders who try to log village lands (inside or outside the park) without making the proper financial arrangements. Under these conditions, the director's plan to "empower" villagers to monitor forests did not amount to support for their self-regulating, conservation-oriented, "customary" ways. It did not engage a unified community of people who cared about the park, and who together with park staff would challenge greedy and irresponsible outsiders. It amounted to a requirement that villagers should confront their 
co-villagers, village elites, and powerful outsiders, including officials—a recipe for vigilantism and violence.

The attempt to make self-governing, environmentally conscious communities real through managed encounters between villagers and planners produced some strange non sequiturs. A TNC report on a consultation exercise in a park-border village duly recorded that villagers raised the problem of their acute shortage of agricultural land and voiced their frustration at being cut off from their coffee and cacao crops when the park border was drawn in 1992. The report then stated "in this matter, the park managers and the villagers have the same interest in the Park, so it is hoped there would be an agreement with the purpose of preventing the occurrence of something neither party would want" (menghindari hal-hal yang tidak diinginkan bersama) (TNC 2001, 17). Interpreted liberally, this passage demanded village compliance with a state-decreed order, while conveniently ascribing that order to villagers' own desires. Yet at the time the report was written, park-border villagers did not believe that their interests and the interests of the park authorities were the same. They thought their interests were opposed. After so many outsiders had come asking the villagers to describe their problems but had failed to supply any answers, some villagers not only grew weary of "collaborative" planning, some concluded that they should simply help themselves-Pak Ratu and Mama Yonas among them.

\section{Contentious Practices}

From the moment park officials began delimiting boundaries in the unilatera! manner typical of Indonesia's Forest Department, park-border villagers have contested their exclusion from agricultural use of park land. For villagers engaged in swidden cultivation, cutting down trees is an integral component of agriculture. As one villager stated during a dialogue session with park officials:

We move our farms in order to retain soil fertility; we return to the land later; we We move our farms in order do clear the forest (membongkar) but we don't destroy it (tidak merusak). Our question is, will the Park authorities ever agree to that?... We (tidak me we wall use it our way. We doubt it. We want our customary land back and we will use it our way. We cant (Yayasan Tanah Merdeka 2003)

For villagers intent on tree crop production, the goal is to replace less useful trees, "ordinary trees" (pohon biasa) as they put it, by more useful, more lucrative trees. Cutting trees in this part of Sulawesi is also the principal practice through which villagers assert customary rights over land. The pioneer who first clears a patch of primary forest acquires exclusive rights that are inherited by his descendents. These rights include the right of the pioneer to treat the land itself as a commodity, that is, to sell it to another person. Hence the villagers' fury at park officials who had sold or mortgaged "their" land to the foreigners. The scale of this problem was significant. Not only did TNC scientists find that hundreds of hectares of park land, in some places extending ten kilometers inside the borders, were planted with coffee and cacao (TNC 2002b, 2:20), they also confirmed the long history of agrarian land use. Up to 26 percent of the park area was under light or heavy anthropogenic forest, mainly former swidden landhence potentially subject to ancestral claims. ${ }^{12}$

From the perspective of conservationists, the principal problem is that village practices fail to conform to their expectations about harmonious communities deeply in tune with nature. Thus a researcher involved in a German government-funded project, Stability of Rainforest Margins, bemoaned the villagers' lack of systems for "customary" forest management. "Traditional rules on forest resource use are almost absent," wrote Gunter Burkard. "Little restrictions on forest use were developed and no well defined traditional mechanisms to regulate resource use among community members have been created" (Burkard $2002 \mathrm{~b}, 6)$. Villagers in the park border area, he found, also lacked a concept of collective benefit or responsibility. They had no local cohesion and little sense of community or mutual assistance in livelihood matters. Each family took care of itself, and theft of produce was common (Burkard 2002a, 33).

Yet, if we can avoid projecting the value of biodiversity protection onto villagers, it is far from evident why villagers should want to protect "ordinary" trees. ${ }^{13}$ From my observations around the park in 2001 and 2003 I can report that villagers valued useful species and protected them when they were scarce. They avoided cutting trees on steep slopes and stream banks for the pragmatic reason that they did not want to see the fruits of their labor disappear in a flood. If, like Mama Yonas, they planned to restore tree cover on the land they claimed, it was mainly because this practice was consistent with their economic interest, currently focused on cultivating cacao.

From a longer term perspective, the customary system of forest classification and use critiqued by Burkard as not "real" management did in fact manage the element of nature of most concern to villagers. It managed rights to use and sell forest land and products. The system ensured that everyone knew what was theirs so that each could pursue their own livelihood goals without conflict with kin and neighbors. It did not manage what was abundant-ordinary trees-only what was valuable and scarce. The key scarcity of pressing concern to park villagers by 2001 was not the scarcity of trees but the scarcity of agricultural land caused by the Forest Department's unilateral imposition of a forest boundary that excluded them from their "customary" land frontier. ${ }^{14}$

\section{Commoditization for All?}

The Nature Conservancy was not ignorant of the commodity values forgone by villagers when they were excluded from the park, but it seriously 
underestimated the degree to which the villagers calculate their economic interest. The "income generating projects" (honey marketing, butterfly collecting, white-water rafting, ecotourism) TNC introduced to offset the villagers' losses and introduce them to the value of conservation foundered on the villagers' economic calculus. The income these projects produced (if any) was far lower than the value of their labor at local daily wage rates, and substantially less than the profits to be made from cacao. As Siebert demonstrated, villagers readily phased out rattan collection when it was no longer cost effective. They roundly rejected the logic Michael Dove dubs "rainforest crunch" - the logic that assigns poor people to the least lucrative economic niche (Dove 1996). They assessed their participation in TNC-sponsored conservation-awareness-building activities by the same market calculus. As one villager trained by TNC to help run village activities observed, "We got a certificate from those trainings, but what can you do with a TNC certificate? It is not accepted at the bank."

Recognizing these problems, conservation agencies are keen to experiment with a new generation of conservation projects that take the market orientation of villagers more seriously. The goal is to "accelerate development of markets for forest ecosystem services (such as watershed protection, biodiversity conservation and carbon storage), to expand markets of sustainably produced forest products and to advance markets that serve the interests of forest communities." ${ }^{\text {s5 }}$ The assumption of these projects is that communities can be induced to manage forests sustainably not because it is their custom to do so, or because they have direct use for forest products, but rather because the economic incentives can be put in place to entice them. Yet there are two problems with this approach, as its proponents acknowledge.

First is the problem of the incomplete commoditization of nature. Thus far, markets for forest ecosystem services do not exist-they are still to be developed. The difficulties are formidable, not least because the costs and benefits of these "services" are separated by vast differences of scale. It was to make sense of jumping scales that park-border villagers devised their creative narrative about "nine nations" and their hidden agenda. Second, costs and benefits are separated by differences of power. Forest villagers seldom have secure tenure over forests, and so they are not in a position to sell forest-protection services. They are not in a position to commoditize nature. Much as they would like to do this, they have no effective means to follow the example of the officials who figured out a way to sell the park to "nine nations." The most they can do is to find ways to realize commodity values from the material they have at hand-forest products, and the agricultural products that replace the trees. Their effective, on-the-ground power to realize these values should not be underestimated. Indeed, TNC's program to produce nature-loving natives can be read as a recognition of the villagers' de facto powers to turn nature to a profit, even as it attempted to contain them. Yet on the scale of the park as a whole, should its nature-protection "services" ever be commoditized, without doubt the benefits would continue to flow to members of the elite —officials and entrepreneurs, often in collusion-who are in a position to grab and monopolize them by legal and illegal means. If conservation organizations proved incapable of shifting the market orientation of villagers, they have even less capacity to control the rapacity of entrenched elites, and no amount of planning, consultation, or micromanagement will change that fact.

\section{Real Conservation}

In this chapter I have examined contested commodifications and the project of producing nature and nature-loving natives in Indonesia's forest zone. Although conservation advocates envisage pristine forest as a priceless treasure that defies commodification, villagers contending with conservation agendas see the forest as a source of commodities-forest products, agricultural products, and land, each of which can be used directly or sold as sources of livelihood. Villagers project their own profit-seeking agendas onto the various parties who speak in the name of conservation-a reading that makes sense of many of the practices they observe, and fills the gap between their knowledge of who actually profits from park protection and the claim of conservationists to protect nature for the broader public good.

Unlike the villagers, and observing the situation from a vastly different position, I am prepared to take the agenda of the conservation organizations operating around the Lore Lindu National Park at their word. Although it is true that some individuals and corporations profit from conservation programs, in Sulawesi and in many other places park-based conservation as it is currently implemented is heavily subsidized by governments and individuals concerned with the public good. It is subsidized because it is unprofitable. It is unprofitable because nature's "services" are incompletely commoditized. Should they be completely commoditized, they would be even more vulnerable to destruction, for the reasons Karl Polanyi pointed out. This is the impossible context in which conservationists project an image of villagers as natives in tune with nature, and attempt to engage them as partners in a countermovement for the future of the planet. They run up against the hard reality that Southeast Asians, including highlanders on the forest edge, have been market subjects for at least a century, with consequences that cannot be wished away or readily reversed. 